\title{
The Research of the Green Management Ability of the Government
}

\author{
Tiantian $\mathrm{Gu}$ \\ School of Economics and Management \\ Zaozhuang University \\ Zaozhuang, China
}

\author{
Xiaoxiang $\mathrm{Li}^{*}$ \\ School of Economics and Management, \\ Zaozhuang University \\ Zaozhuang, China \\ *Corresponding Author
}

\begin{abstract}
With the development of China's economy, industrialization is accelerating, the ecological and environmental problems become increasingly serious. Today, environmental pollution problem is serious, the consumption of natural resources is increasing, there are more and more ecological problems, and the sustainable development of our economy is facing great challenge. Ecological issues are involved in the mutual coordination of social public interests, ecological interests, and economic interests; therefore, protecting ecology is the responsibility of the country' $s$ administrative organs, it is urgent for the government to improve the green management capacity. Government's green management ability refers to a kind of capability or power which a government pursues to realize a harmonious idea or goal between human and the nature and successfully use the idea or goal into its whole public management. This paper analyzed the situation and reasons of China's green management ability and gave some suggestions for improvement, which can be a reference for the increase of China's green management ability.
\end{abstract}

Keywords-green management; government ability; ecological environment

\section{INTRODUCTION}

The green management of government refers to the public management that follows the law of the coordination and interaction between the economy, society and ecology, fully reflects the requirements of ecological laws, takes the ecological civilization and green economy as the basic value orientation and promotes the ecologicalization of society and economy. The green management ability of government ability or power that required by the government in realizing the concept of the harmonious development between man and nature and making the concept penetrate to the whole process, all staff and all activities of the public management. It is also called the management ability of sustainable development. At the end of 2007, the State Council issued "The '11th Five-Year' Plan of National Environmental Protection". It definitely raises the construction tasks of the green management ability of government in the new period, and mainly includes seven items: the construction of advanced environmental monitoring and warning system; the construction of perfect supervision system of environmental law enforcement; the construction of environmental accident emergency system; the improvement of environmental comprehensive assessment ability; the construction of "gold ring project" (i.e. national and local environmental protection information system); the enhancement of the supporting ability of environmental science and technology innovation; the improvement of team construction and personnel cultivation.

\section{The Status of the GREEN MANAGEMENT ABILITY OF CHINESE GOVERNMENT}

\section{A. The Supervision System of Environmental Law Enforcement}

Up to now, China has formulated 9 laws of environmental protection and 15 laws of natural resources, issued more than 50 administrative laws and regulations about the environmental protection, nearly 200 departmental regulations and normative documents, more than 10 environmental protection laws and regulations of the army and more than 800 national environmental standards and approved and signed almost 51 multilateral international environmental treaties and 1600 local environmental regulations and local government acts formulated by local people's congresses and governments. Now, a dozen of provinces and municipalities have formulated local regulations or the local documents of the government related to the development of circular economy.

\section{B. Environmental Information System}

Continually promote the construction of office business resource system, golden gate, golden tax, financial regulation, macroeconomic management, golden fiscal, golden shield, golden auditing, golden insurance, golden-agriculture, golden quality, golden water and realize the full coverage of government businesses. Continually establish and improve the urban management information system. It mainly includes the planning subsystem (provide basic information and analysis data of urban management planning) and municipal subsystem (provide the basic information and analysis data of the management of city road, highway, bridge, tunnel and underground pipelines). Besides, it also includes water affairs subsystem, house land subsystem, environmental protection subsystem, virescence subsystem, 
city appearance and sanitation subsystem, the management information subsystem of urban construction supervision.

\section{Crisis Management System}

Since SARS, the crisis management has gradually developed in China. Specifically expressed as : the public emergencies in China are divided into five categories according to the occurrence process, property and mechanism, including natural disasters, disaster accidents, social security, public health and economic turbulence; The public crisis early warning system is basically established. Now, the major public crisis early warnings of China are the early warning of natural disasters and the early warning of large-scale infectious diseases. The mode of organizing temporary organizations to exclusively manage crises when they happen, and one or more specific departments will deal with crises. The legal system for dealing with public crisis is constantly improving.

\section{The PROBlems of GREEN MANAGEMENT ABILITY OF CHINESE GOVERNMENT}

However, according to the realistic requirement of scientific development and the objective of green management, the green management of Chinese government is still in the initial stage of development. The new green management functions are deficient and there are many problems of "government failure" and "deficiency", resulting in the great loss of public resources. Taking environmental protection as an example, the development of economy has excessively utilized the environmental resources and capacity. The government has adopted some measures to intervene in the resources allocation. However, the intervention not only fails to develop the environmental policies that effectively regulate the rational utilization of natural resources and the pollutant emissions, but also results in the decision-making error of the government due to the insufficient information or the role of economic man of civil servants. Then the administrative behavior of government will greatly deviate from the established objectives.

Environmental protection system also has problems. The environmental protection department is in a vulnerable position in the government compared with other departments. It does not have independent financial rights and the rights of personnel appointment and removal, and it greatly depends on the government, resulting in the great limitations in environmental protection. Besides, due to the particularity of Chinese systems, some cities have established the Environmental Protection Bureau while environmental protection is managed by the other departments. For example, environmental protection is managed by the department of land and resources in Hainan. Environmental protection function of the government is greatly dispersed among the relevant departments.

There are problems in crisis management. No matter the developed countries or developing countries, various public crises occur frequently in reality, brining great negative effects to the economic construction and the life of citizens. As the legal system of crisis management is not perfect in
China, sometimes there is no law in crisis management. In 2003, before the outbreak of SARS, China has not established any special law for dealing with public health emergencies. Compared with foreign countries, Chia also does not have any permanent and independent crisis management institution. It usually establishes temporary and special management institutions for dealing with crisis and coordinating work after disasters happening. Due to the deficiency of specialized crisis management institutions, the continuity of the crisis management in China is deficient and the effective communication between departments is also deficient. They often absolve themselves from responsibility when crisis happening, greatly affecting the ability of government in dealing with crisis.

Although the management system of Chinese government has undergone several major reforms, it cannot meet the requirements of the socialist market economic system in many aspects. It is mainly reflected in: There is serious "deficiency" in the Ecological management function allocation of the government; There are excessive micro managements and macroeconomic regulation and control distortion, and they greatly rely on administrative examination and approval; Functions of government and enterprise have not been separated, and the government and asset institutions have not been separated, and the function of decision and execution have not been separated; The governance of local division and the function segmentation of department destroy the unity of the ecology itself.

\section{THE SUGgestions ON THE IMPROVEMENT OF THE GREEN MANAGEMENT ABILITY OF GOVERNMENT}

\section{A. Establish and Improve Relevant Mechanisms, Laws and Regulations}

Crisis early warning and control mechanism can be divided into the detection, identification, diagnosis and evaluation of crisis signs. The construction of the special agencies of early warning, monitoring, quick response and others are conducive to the scientific detection of social change. It warns the critical breakthrough of social stability and constructs a complete command system that can identify the overall stability of the country. Once the crisis happens, the decision maker of the government must make the most reasonable decision in the shortest time and take decisive measures to control the crisis. However, it requires the establishment of efficient response mechanism.

Formulating the unified law to deal with emergencies and dealing with emergencies and other public emergencies with legal means are conducive to improving the treatment efficiency and effect. "Emergency law" is a law for dealing with public emergencies formulated by the United States. As the basic guideline for dealing with the crisis, "emergency law" determines the legal principle of resisting crisis according to laws and maximally protects the legitimacy and authority of the government during public emergencies. 


\section{B. Improve Information Standard}

Aiming at the problems of the government exposed in dealing with public crises, the information management ability of the government should be improved. Firstly, the government should establish the consciousness of information publicity and get rid of the consciousness of fearing panic and chaos, so that the right to know of citizens can be protected; Secondly, the government should start establish information systems to improve the ability of the government in information collection and processing and to ensure that the government can make scientific and rational decisions; Finally, the information communication between government, social organizations and the public should be strengthened and the latest information about the crisis should be released in time for avoiding the spread of rumors.

The government can improve the information standards through the following measures: establish and improve the green information publicity system; publish the green information closely related to the livelihood of citizens; disclose the green information with high social concern in time.

\section{Improve the Supervision and Evaluation Standards}

Restrict government ecological management behavior and strengthen social supervision. Social supervision mainly refers to the supervision of the society and citizens on the government and its administrative personnel, including the supervision by public opinion, the supervision of social groups and the supervision of citizens. The ecological administration of the government cannot be separated from the social supervision. The supervision by public opinion should not only advocate the administrative idea of the government on saving resources and protecting environment, but should also carry out the actual reports on the status of the government on dealing with resources and environment problems coping with ecological crisis, especially the administrative inaction and inappropriate acts of the government in the protection of resources and environment. Citizens and social organizations should make full use of the right to know, the right of participation and supervision rights, and widely participate in the process of the ecological decision-making and ecological management of the government. Generally, the behavior of the government on managing resources and environment should be widely supervised by public opinion, media, group organizations and the public, which prompts the realization of the ecological administration of government.

Improve the performance evaluation index system and emphasize ecological benefit indicators. Now, the government pays too much attention to the economic benefit index while evaluating the government departments at all levels. Especially, they take the local GDP as the standard of growth, and social benefit index and ecological benefit index are deficient. Therefore, it is urgent to introduce ecological indicators into the performance evaluation index system and highlight the status and role of ecological benefits index. Specifically, take the social ecological index as the main criteria for measuring the performance of local governments, such as the proportion of environmental investment to the
GDP, the area of soil and water pollution control, resource saving rate per unit GDP, the satisfaction of residents on the surrounding environment and others, and increase the weights of these indexes along with the development of economy and society.

The government should take the concept of green economic management as the guidance, pay attention to the formulation and implementation of green standard system, implement green GDP system and green assessment system and gradually form a perfect management system of green economy. On the one hand, the government should impose high penalties on the acts violating environmental laws and regulations for improving the consciousness of enterprises on saving resources and protecting environment. On the other hand, the government can provide appropriate reward to the enterprises which pay attention to ecological responsibility and green management, and provide certain financial subsidies to the enterprises that consciously carry out environmental improvement for encouraging enterprises to adopt energy-saving and emission reduction equipment. Moreover, the government should also guide enterprises to change the mode of growth and technical methods.

\section{Improve Input Standards and Strengthen Green Financial Resources}

External diseconomy behaviors, such as environmental pollution and ecological destruction, will detract from the value of ecological environment. However, as environmentalists cannot obtain benefits from the external economic behaviors that are beneficial to maintain and improve the value of ecological environment, such as environmental protection, or even those behaviors will damage their interests, such external economic behaviors will not happen. Then, the ecological administrative compensation of the government is necessary. The government pays for ecological impaired person who are not financially rewarded for protecting the environment, encouraging the emergence of the external economic behaviors of environment. The sources of the ecological administrative compensation of government can come from the following methods: 1 . Set ecological benefit tax. As the improvement of the ecological environment benefits all citizens, the ecological benefit tax can be levied from all citizens; 2. Levy ecological loss fee. It aims at the population involved in ecological development and utilization; 3. Collect environmental resource utilization fee. As the major owner of environmental resource, the state can auction its value in use and collect the environmental resource utilization fee as the national ecological compensation; 4. Establish ecological compensation fund. The state raises funds from the society by issuing ecological lottery tickets for making up the shortage of national ecological compensation funds.

\section{CONCLUSION}

Green and sustainable development is the inherent requirement of economic development, and it is imperative for the government to improve its green management ability. At present, the green management ability of our government 
is still in its preliminary stage, there are a lot of problems that need to be improved. This paper argues that, we can improve the input specification from establishing and perfecting the mechanism, laws and regulations, perfecting the information standard, perfect the supervision and evaluation standard, etc.

\section{REFERENCES}

[1] Anonymous(2010). NA Co survey:Cost cutting drives counties to green government efforts. The American City \& County, 28-32.

[2] Anonymous(2008). Government Business Counci:Federal 'Green Government' Initiatives Gaining Momentum According to Study. Politics \& Government Week,55-59.

[3] Antony Brown(1980). Technical Assistance to Rural Communities:Stopgapor Capacity Building. Public Administration Review,Vol40,No3.

[4] R.T.Lenz(1980). Strategic Capability:A Concept and Framework for Analysis.Academy of Management Review,Vol 12,No 4.

[5] John P. Coleman(1975).Local Government Viability,Paper presented at American Society for Public Administration National Conference.Chicago.

[6] Yong Geng, Brent Doberstein(2007). Greening government procurement in developing countries: Building capacity in China.Journal of Environmental Management, 33-37. 